\title{
DEFICIÊNCIAS OU DIVERSIDADE HUMANA?
}

\author{
DEFICIENCIES OR HUMAN DIVERSITY? \\ ¿DEFICIENCIAS O DIVERSIDAD HUMANA?
}

Esther Maria de Magalhäes Arantes*

Resenha do livro: Solomon, A. (2013). Longe da árvore: pais, filhos e a busca da identidade. Rio de Janeiro: Companhia das Letras, 1050 p.

O título do livro se refere ao ditado segundo o qual os frutos náo caem longe da árvore, significando que maçâs são os frutos esperados das macieiras e laranjas, das laranjeiras - pelo menos até que a engenharia genética modifique tudo isto. Não se espera que abacates possam ser colhidos em pés de goiabas ou coqueiros. Caso isso aconteça, diz-se que são frutos longe da árvore. Como pensar as características desses frutos em relação à árvore e ao meio onde se encontram?

Solomon se utiliza desse ditado para pensar as identidades entre os humanos, fazendo uma distinção inicial entre identidade vertical e identidade horizontal. O livro é dedicado a esta última.

Devido à transmissão de identidade de uma geração para a seguinte, a maioria dos filhos compartilha ao menos algumas características com os pais. São o que chamamos de identidades verticais. Atributos e valores são transmitidos de pai para filho através das geraçóes, não somente através de cadeias de DNA, mas também de normas culturais compartilhadas. A etnia, por exemplo, é uma identidade vertical (p. 12).

Muitas vezes, porém, alguém tem uma característica inata ou adquirida que é estranha a seus pais e, portanto, deve adquirir identidade de um grupo de iguais. É o que chamamos de identidade horizontal. [...] Ser gay é uma identidade horizontal; a maioria das crianças gays tem pais heterossexuais e, embora a sua sexualidade não seja determinada por seus iguais, elas

\footnotetext{
* Pontifícia Universidade Católica do Rio de Janeiro, Rio de Janeiro, RJ, Brasil; Universidade do Estado do Rio de Janeiro, Rio de Janeiro, RJ, Brasil.
} 
aprendem a identidade gay observando e participando de uma subcultura fora da família (p.12).

Considerando que, em geral, temos dificuldades em aceitar ou não estamos preparados para ter filhos que apresentam necessidades desconhecidas para nós, o livro é dedicado às perplexidades e aos esforços de famílias de crianças que nasceram ou adquiriram características diferentes dos pais:

As crianças que descrevo aqui têm condiçóes horizontais que são estranhas a seus pais. Elas são surdas ou anãs; têm síndrome de Down, autismo, esquizofrenia, ou múltiplas deficiências graves; são prodígios; são pessoas concebidas por estupro ou que cometem crimes; são transexuais. $\mathrm{O}$ desgastado ditado diz que a maçã não cai longe da árvore, o que significa que uma criança se assemelha a seus progenitores; essas crianças são maçãs que caíram em outro lugar - algumas, um par de pomares de distância, outras, do outro lado do mundo. No entanto, miríades de famílias aprendem a tolerar, aceitar e, por fim, celebrar crianças que não são o que elas originalmente tinham em mente. Esse processo de transformação é com frequência facilitado e, às vezes, confundido por políticas de identidade e progressos médicos que se infiltraram nas famílias em um grau que seria inconcebível há vinte anos (p. 16).

Embora o livro tenha 1050 páginas (sendo 813 dedicadas aos capítulos e as demais distribuídas entre Agradecimentos, Notas, Bibliografia e Índice Remissivo), está organizado de forma a que cada capítulo possa ser lido independentemente, não necessitando seguir nenhuma ordem pré-estabelecida, a não ser, talvez, o primeiro capítulo, onde o autor faz consideraçóes de ordem mais geral, ajudando-nos a entender as motivaçóes que o levaram a pesquisar o tema e a escrever o livro.

Em 1993, fui designado pelo New York Times para investigar a cultura surda. Minha suposição sobre a surdez era que se tratava de um déficit e nada mais. Ao longo dos meses que se seguiram, me vi arrastado para o mundo dos surdos. A maioria das crianças surdas nasce de pais que ouvem, e esses pais priorizam com frequência o funcionamento no mundo da audição, gastando uma enorme energia na fala oral e na leitura labial. [...]. Muitos topam com a identidade surda na adolescência, e isso significa uma grande libertação. Eles entram em um mundo que valida os sinais como lingua- 
gem e se descobrem. Alguns pais não surdos aceitam esse novo e poderoso desenvolvimento, outros lutam contra ele.

A situação toda me parecia impressionantemente familiar porque sou gay. Gays em geral crescem sob a tutela de pais heterossexuais que acham que os filhos estariam melhor se fossem como eles e, às vezes, os atormentam, pressionando-os a se adequar. Com frequência, essas pessoas homossexuais descobrem a identidade gay na adolescência ou mais tarde, encontrando grande alívio nisso (p. 13).

Como jornalista, Solomon escreve para o grande público sem, no entanto, simplificar as questóes, apresentando os dilemas, os sofrimentos, as dificuldades e também as alegrias envolvidas na luta pela afirmação das identidades horizontais, para que sejam vistas como diferenças do humano e não como doenças ou anormalidades que devem ser curadas ou eliminadas. Assim, embora o livro não se dirija a especialistas, estes podem se beneficiar de sua leitura, uma vez que a pesquisa de Solomom é, em muitos aspectos, surpreendente.

Um dos aspectos tratados no livro e que causa grande impacto no leitor são os inúmeros e dolorosos tratamentos e cirurgias aos quais se submetem as crianças, para que se curem ou apenas para que tenham a aparência modificada, aproximando-se das pessoas ditas normais ou comuns.

Quando comecei a escrever sobre os surdos, o implante coclear, que pode proporcionar uma espécie de fac-símile da audição, era uma inovaçáo recente. Ele foi saudado pelos progenitores como uma cura milagrosa para um defeito terrível e foi lamentado pela comunidade surda como se fosse um ataque genocida a uma comunidade vibrante. Desde entâo, ambos os lados moderaram a retórica, mas a questáo é complicada pelo fato de que os implantes cocleares se mostram mais eficazes quando são feitos precocemente - em bebês, de preferência - e, assim, a decisão é muitas vezes tomada pelos pais antes que a criança possa ter ou expressar uma opiniáo informada. Ao observar o debate, eu sabia que meus próprios pais corajosamente dariam consentimento para um procedimento precoce paralelo, se ele existisse, que garantisse que eu me tornaria heterossexual (p. 13-14).

[...] Depois, uma amiga minha teve uma filha aná. Ela se perguntava se deveria educar a filha para se considerar como todo mundo, apenas menor; se deveria providenciar para que a filha tivesse modelos de comportamento de anão; ou se deveria investigar sobre alongamento cirúrgico dos mem- 
bros. Enquanto ela falava de sua perplexidade, identifiquei um padrão. Eu ficara perplexo ao notar minha afinidade com os surdos, e agora me identificava com uma aná; perguntei-me quem mais estaria lá fora esperando para se juntar à nossa alegre turma (p. 14).

Terapias para a cura gay, às quais Solomon se submeteu na juventude; operaçóes de adensamento de ossos e músculos para aumentar alguns centímetros na altura da criança aná, para que venha a se parecer com um adulto de baixa estatura; implante coclear e impedimento da criança surda de se comunicar através de línguas de sinais; cirurgias para modificação dos olhos, língua e pescoço para crianças com Síndrome de Down, etc., além de uma política de institucionalização e segregação em asilos ou instituiçôes especiais, têm propiciado uma polarização do debate, na medida em que nunca antes no Ocidente estivemos tão preparados socialmente para aceitar as chamadas deficiências como diferenças do humano e, contraditoriamente, nunca antes como agora a medicina e a engenharia genética buscam a cura e a eliminação para o que consideram doenças, deficiências e anormalidades.

Historicamente, segundo o autor, os movimentos de direitos civis e humanos nos EUA vieram na seguinte sequência: a liberdade religiosa, o voto feminino e os direitos raciais; depois, a liberação gay e, finalmente, os direitos dos deficientes - cabendo esclarecer que "esta última categoria tornou-se um nome genérico para diferenças de muitos tipos” (p. 41).

Independentemente das especificidades de cada identidade horizontal descrita e analisada pelo autor em cada um dos capítulos, a questão de fundo problematizada pelo livro é a tensão que se instala a partir das lutas pelos direitos dos deficientes, que buscam encontrar um lugar para a diferença, e daqueles que acreditam que algumas dessas diferenças são doenças e deficiências que devem ser tratadas e curadas e, se possível, prevenidas e erradicadas.

É um debate polarizado que opóe, por um lado, desde os que se posicionam contrários ao exame genético e ao Projeto do Genoma Humano (porque tais projetos buscariam o homem perfeito), incluindo pessoas que buscam deliberadamente parceiros com as mesmas características para ter filhos com as mesmas identidades e, por outro lado, desde os que se posicionam a favor das pesquisas para erradicar e prevenir as deficiências e doenças até os que defendem a esterilização e a segregação das diferenças.

Assim, o termo "doença" tem sido utilizado, algumas vezes, "para depreciar um modo de ser" e o termo "identidade" para afirmar e "validar essa mesma maneira de ser" (p. 15). Trata-se, segundo o autor, de uma falsa dicotomia e de 
um empobrecimento do debate, na medida em que "muitas condiçóes são tanto doença como identidade, mas só podemos ver uma se obscurecermos a outra" (p. 15-16).

A proposta do livro é que precisamos de um vocabulário em que os dois conceitos não se oponham mas sejam aspectos compartilháveis de uma mesma condição, possibilitando uma compreensão outra do que seja saúde (p. 16).

Recebido em 30 de novembro de 2014 Aceito para publicação em 31 de março de 2015

DOI: $10.1590 / 0103-56652015000100015$ 